\title{
Marcello Caetano antes do marcelismo
}

\author{
Luís ReIS TORgal \\ Universidade de Coimbra \\ Marcello Caetano Before Marcelism
}

\begin{abstract}
RESUMEN
Normalmente se enjuicia el marcelismo como un fenómeno aislado, lo que lleva a considerar a ese período de cerca de seis años (1968-1974) en que presidió el Gobierno como el de una "renovación en la continuidad", o incluso como el de una «liberalización bloqueada». Sin embargo, para entenderse debidamente el marcelismo es necesario conocer a Marcelo Caetano y su evolución. Esa indagación nos llevaría a preguntarnos si el Marcelo Caetano del "Estado Social" de los años sesenta y setenta es estructuralmente distinto del Marcelo de juventud que asumió, aún más que el propio Salazar, una ideología revolucionaria de derechas. Obviamente, no pretendemos responder a esa importante pregunta, sino presentar simples hipótesis en este ensayo tentativo.

\section{PALABRAS CLAVE:}

\section{ABSTRACT}

Normally, "Marcelismo» is defined as an isolated phenomenon, a period of approximately 6 years (1968-1974) thought of as "A Renovation in Continuity" or even more so as «A blocked liberalization». However, to fully grasp "Marcelismo» one must have knowledge of Marcello Caetano and his evolution. That research poses the question if Marcelo Caetano of the «Social State», from the sixties and seventies, is structurally different from the Marcello Caetano of his youth who assumed, more than Salazar, a revolutionary right wing ideology. We do not obviously want to respond to that important question, but instead present hypotheses, in this research essay.

KEYWORDS:

Marcelism. Caetano's Political and Social Thought. «Estado Novo». Salazarism. Caetano's Reformism
\end{abstract}

Marcelismo. Pensamiento político de Marcelo Caetano. Estado Novo. Salazarismo. Reformismo marcelista 


\section{AS INTERPRETAÇÕES IDEOLÓGICAS E MEMORIAIS E A INTERPRETAÇÃO HISTORIOGRÁFICA DE MARCELLO CAETANO}

As interpretações da «esquerda» acerca do significado do Marcelismo, a começar naquelas que advinham do Partido Comunista Português ${ }^{1}$, consideravamno, obviamente, ainda que com algumas cambiantes, uma «tentativa [desesperada e tardia] de salvar a Ditadura», ou seja, o Estado Novo de Salazar, por uma via pseudoliberal, logo desmentida pela prática ${ }^{2}$. Até certo ponto diferente - com outros pressupostos, na lógica da «liberalização bloqueada», que poderia supor ou reproduzir um juízo crítico mais dirigido aos «ultra» do que a Marcello Caetano foi o que acabou por pensar Sá Carneiro, ao afastar-se, desiludido, da que foi chamada «ala liberal» da Assembleia Nacional, «ala» essa que acabou por se diluir, e a que pertencera como deputado da União Nacional (depois Acção Nacional Popular), aliciado pela esperança de uma abertura política do regime ${ }^{3}$.

Por sua vez, um antigo compagnon de route de Marcello, o líder nacional-sindicalista dos anos trinta Rolão Preto, numa «carta aberta» que Ihe dirigiu em Julho de 1972, lembrou o «camarada político doutros tempos», o «Integralista» com «acentuado espírito político», da «nova geração» anunciada no inquérito de Agathon (Henri Massis e Alfred de Tarde) ${ }^{4}$, que pretendia «substituir a mística da liberdade pela mística da ordem». ${ }^{5} \mathrm{E}$ o antigo «chefe» dos «camisas azuis», convertido à democracia (exilado político e, desde de 1949, apoiante das candidaturas de oposição, de Norton de Matos, Quintão Meireles e Humberto Delgado), ainda dizia acreditar (mas talvez não) que Marcello, apesar das críticas veladas ou abertas que lhe movia - o facto de apesar de monárquico, ter justificado a continuação da república em Portugal (no III Congresso da União Nacional, de 1951, esclareçamos

\footnotetext{
1 Ver diversos documentos do PCP, a maioria deles emitidos na época do Marcelismo e outros posteriormente publicados (de Álvaro Cunhal), na obra: O governo de Marcelo Caetano, tentativa de salvar a Ditadura. Cadernos de história do PCP 5. S.I., Editorial «Avante!», 1997.

2 A mesma ideia tem sido, por exemplo, e foi-o na época do Marcelismo, afirmada à saciedade por Mário Soares ou, quanto ao caso específico das leis da imprensa, por Alberto Arons de Carvalho, no livro publicado em 1973, A Censura e as leis da Imprensa (Col. «Que país?». Lisboa, Seara Nova, 1973), recentemente reeditado (Coimbra, Minerva, 1999). Recordem-se também as obras, implicitamente críticas, de Moraes Editores, que constituíam a colecção «Hoje a Amanhã», publicadas em 1973-1974, algumas já depois do «25 de Abril», da autoria, entre outros, de Francisco Sarsfield Cabral, Mário Murteira, Rogério Fernandes.

3 Ver, por exemplo, o seu depoimento in Ser ou não ser deputado, Lisboa, Arcádia, 1973, pp. 7-41, e a entrevista conduzida por Jaime Gama, publicada no jornal República, em 11 de Janeiro de 1972, e que originou o opúsculo A liberalização bloqueada (Lisboa, Moraes Editores, 1972).

4 Trata-se da obra de autoria de Agathon (pseudónimo colectivo dos nacionalistas franceses ligados à Action Française, Henri Massis, 1886-1970, e Afred de Tarde, 1880-1925), Les jeunes gens d'aujourd'hui. Le goût de l'action, la foi patriotique, une renaissance catholique, le réalisme politique. Paris, Librairie Plon, 1913. A obra de Agathon era, desde o seu início, uma das obras aconselhadas pela revista integralista lusitana Nação Portuguesa (ver, por exemplo, Nação Portuguesa. Revista de Filosofia Política, Coimbra, França e Arménio, Ano I, n. ${ }^{\circ}$, Julho de 1914, extratexto no fim do número, em páginas azuis). 3-7.

5 Cfr. Cartas Políticas. 2. Carta aberta ao Doutor Marcello Caetano, Lisboa, 1972, nomeadamente pp.
} 
nós) e de considerar, estranhamente, que já existia no país "suficiente liberdade de expressão de pensamento" 6 -, acabaria por aceitar a existência dos partidos, que lhe pareciam ser uma necessidade política ${ }^{7}$.

Entretanto, um intelectual monárquico, Fernando Pacheco de Amorim, apaixonado pela ideia de defesa da integridade e unidade de Portugal, que abrangia o Continente, as Ilhas Adjacentes e as Províncias Ultramarinas, atacava o que considerou o «neocolonialismo» marcelista, entendendo que Marcello, durante a Presidência do Conselho, apenas renovara as suas ideias de política colonial apresentadas desde sempre, o que levaria necessariamente à independência das terras da África ${ }^{8}$. Ao invés, a própria obra de António de Spínola, o famoso livro Portugal e o Futuro, publicado em Fevereiro de 1974, colocando-se num plano completamente diferente ao que foi a ala considerada então da «extrema direita», representada, nesta linha ultramarina, por Pacheco de Amorim, ou seja situando-se, antes, numa «direita moderada», democrática, e europeísta, sem citar Marcello e o Marcelismo, fazia uma crítica implícita à realidade política do tempo - em que Spinola fora interveniente, como Governador Geral da Guiné e advogava o reequacionamento de Portugal, incluindo nele uma verdadeira "solução federativa», único modo de manter integrados os territórios de África ${ }^{9}$. Essa posição tinha, sem dúvida, subjacente, de forma implícita, a ideia de que as «ambiguidades» de Marcello Caetano (agudamente salientadas por Amorim, anotemos nós) não fariam sair Portugal do impasse a que chegara. Daí o carácter «revolucionário» que se atribuiu ao livro, o que levou Spínola a abandonar o cargo de vice-chefe do Estado-Maior das Forças Armadas, para que fora nomeado em Janeiro de 1974.

Ou seja, Marcello Caetano foi, no seu tempo, criticado à direita e à esquerda (uma esquerda e uma direita nunca organizadas e integradas no sistema político e que sempre viveram como «posição» ou «oposição» ilegal ou, quando muito, consentida).

Por sua vez, Marcello Caetano, nas suas memórias, já escritas no Brasil, no tempo do seu exílio, deixou uma imagem ambígua da sua acção política. Em poucas palavras, manteve a sua fidelidade a Salazar, mas salientou também, o que corresponde à realidade, a frontalidade que assumiu nas suas posições,

6 Ob. cit., p. 11.

7 Idem, p. 8 ss.

8 Na hora da Verdade. Colonialismo e neo-colonialismo na proposta de lei de revisão constitucional, Coimbra, Edição do Autor, 1971. Curiosamente Pacheco de Amorim participara no chamado «movimento da Mealhada» de Outubro de 1946, que tem esse nome porque militares do Batalhão de Cavalaria 6, do Porto, que se deslocavam em direcção a Lisboa com o sentido de fazer cair o governo de Salazar, acabaram por se render na Mealhada. Marcello, nas suas Memórias, alude a isso, só referindo curiosamente o nome de Pacheco de Amorim e afirmando que «posteriormente continuaria a dar mostras do seu desequilíbrio» (Minhas Memórias de Salazar. Lisboa, Verbo, 1977, p. 270)

9 Cfr. Portugal e o Futuro. Análise da conjuntura nacional, Lisboa, Arcádia, 1974, sobretudo os caps. «Os fundamentos de uma estratégia nacional» e «Uma hipótese de estruturação política da Nação». Ver, relativamente à «solução federativa», por ex., p. 160. 
quando com ele não concordava. Ele era - nas suas próprias palavras - o “amigo incómodo» ${ }^{10}$. Mas, por outro lado, deu a entender que desde cedo se formou um grupo que se opunha às suas ideias e à sua acção, que contra ele conspirava, considerando também como vítima dessa conspiração o próprio presidente da República, Craveiro Lopes. Tratava-se do grupo que identificava com os «monárquicos» (nomeadamente Mário de Figueiredo e Santos Costa), que não lhe terão perdoado a sua posição contrária em relação ao eventual regresso da Monarquia. Não se debruçou então directamente sobre o seu governo, mas ficou a ideia de que essa ala, transmudada, teria sido afinal aquela que não o deixara governar numa política mais liberal

Agora, quando se celebram 100 anos do nascimento de Marcello Caetano, mantém-se uma tendência para entender o Marcelismo mais como uma «Primavera», embora frustrada, que tem como referência imagética as suas "conversas em família», do que como "Renovação na continuidade» do Salazarismo, esquecendo uma perspectiva mais alargada de Marcello, ou seja, o seu passado, o que é fundamental para entender o Marcelismo. Ou, pelo menos, há a tendência para falar de Marcello Caetano - conforme parece suceder de modo indirecto e no contexto de um drama político-universitário dos anos sessenta (o drama passase ficticiamente em Janeiro de 1962 e um ano depois), embora sem nunca nomear o seu nome, com uma polémica peça de teatro de Diogo Freitas do Amarall ${ }^{11}$ como aquele que, tendo uma lógica de liberalização, na sua condição de reitor da Universidade, acabou, na prática política, por «atraiçoar» essa sua posição a partir do momento em que se tornou ministro, acabando por ser pressionado pelos «ultra» e por «morrer» politicamente.

Há, por vezes, a intenção, na prática «branqueadora», de reforçar a ideia do indesmentível valor intelectual de Marcello, das suas qualidades de jurista, de professor e de político dialogante, de resto um pouco na continuação do que sucedeu no seu tempo. Tratando-se de um sucessor de Salazar - tal como o próprio Marcello fez questão de afirmar no seu discurso de tomada de posse ${ }^{12}$-, não se omitiu, obviamente, nessa altura nem em outros momentos, o seu passado "salazarista» nem a ideia de "continuidade», mas desejou-se apresentá-lo de forma «orientada», lembrando, acima de tudo, o homem «como os outros», o «Homem de Diálogo». Assim sucede no denominado «apontamento para uma antologia», editado em 1969 pelas oficiosas «Edições Panorama» sob a forma de dicionário político, ou seja uma selecção de textos seleccionados segundo esse critério, da

10 Minhas Memórias de Salazar, Lisboa, Verbo, 1977, p. 261.

11 O Magnífico Reitor, Lisboa, Gradiva, 2001.

12 O seu discurso de tomada de posse, em 27 de Setembro de 1968, começou com um elogio a Salazar. Mas, para marcar a diferença, Marcello apresentou-se como «um homem comum», ao contrário do seu antecessor: «O País habituou-se durante largo período a ser conduzido por um homem de génio: de hoje para diante tem de adaptar-se ao governo de homens como os outros» («Saibamos ser dignos desta hora». Discurso pronunciado no Palácio de S. Bento, a 27 de Setembro de 1968», in Marcello Caetano, Pelo futuro de Portugal, Lisboa, Verbo, 1969, p. 16). 
autoria de Marcello Caetano, escritos entre 1936 a $1967^{13}$, em que ficou de fora, como era natural, a sua fase integralista, aquela que era, efectivamente, mais demonstrativa da sua posição de «nacionalista» mais radical e de «revolucionário de direita».

Para se entender correctamente Marcello Caetano e o Marcelismo, há que conhecer o seu passado, mais afastado e mais próximo. Mas, não apenas o seu passado universitário, que, na verdade, pelo menos em reflexões que fez desde os anos quarenta ${ }^{14}$, é demonstrativo de uma certa abertura aos problemas dos estudantes, que marcou a sua imagem (no entanto, não esqueçamos - o que frequentemente se omite - que também Salazar fora, tendo em conta a sua formação, um pedagogo actualizado, modelado na obra de Demolins e da École des Roches).

Importa recuar aos seus tempos de juventude, à direcção da revista Ordem Nova, onde defendeu, arreigadamente e de forma polémica, doutrinas integralistas, monárquicas, nacionalistas e católicas, de tipo tomista, para depois, de forma pragmática, vir (como se disse, em 1951) a retirar a última possibilidade de o regime assumir uma via monárquica. É fundamental, igualmente, conhecer as suas posições colonialistas, logo afirmadas em 1926. Só assim se entende bem as posições «coloniais» defendidas depois, ao longo da vida política, manifestando sérias reservas, embora em nome dos «direitos indígenas», à passagem da designação oficial de «colónias» a «províncias ultramarinas», para, «oportunisticamente» (embora com "coerência», no dizer dos seus críticos de «extrema direita»), durante o seu governo, se abrir à possibilidade de uma «autonomia», embora limitada, sem, todavia, aceitar alguma vez o direito das "colónias», ou «províncias ultramarinas» (na linguagem oficial), à autodeterminação e à independência. É relevante ainda conhecer a sua ideologia corporativista, consideranda o Estado Novo como um verdadeiro «sistema corporativo» sempre imperfeito e em busca de concretização, assim como é necessário conhecer os seus discursos e textos sobre a Mocidade Portuguesa, de que foi Comissário Nacional, e sobre a importância de criar «dirigentes», um escol ao serviço do regime, o qual pensou o mais possível numa lógica «integralista», provavelmente com influências do modelo fascista, negadas nas memórias ${ }^{15}$ mas que não podem deixar de se considerar, como veremos.

Desta forma, a expressão «Estado Social» que foi usada no Marcelismo ${ }^{16}$ mais do que a expressão consagrada do seu antecessor, «Estado Novo», em que

${ }^{13}$ Marcello Caetano, Princípios e definições. Textos de 1936 a 1967. Compilados por António Maria Zorro. Lisboa, Edições Panorama, 1969.

14 Ver, por exemplo, Universidade nova. O problema das relações entre professores e estudantes, Coimbra, 1942, e "Universidade e investigação", in Ciência. Revista dos estudantes da Faculdade de Ciências de Lisboa. Ano IV, n. ${ }^{\circ}$, pp. 3-6.

15 Por exemplo, Minhas Memórias, p. 72.

${ }_{16}$ A expressão «Estado Social» foi usada oficialmente, por exemplo, no opúsculo Estado Social. Excertos de discursos proferidos pelo Presidente do Conselho de Ministros Prof. Doutor Marcello Caetano, Lisboa, Secretaria de Estado de Informação e Turismo, 1970. 
se reviu na sua juventude e maturidade — tem afinal um sentido próprio que importa não lateralizar, pois ela corresponde a uma opção política de princípio. Com as devidas distâncias, e sem estabelecer confusão de planos políticos, trata-se de algo idêntico ao que se passou com Mussolini, que optou pelo conceito de «República Social» na sua ficcional República de Salò, depois da queda institucional do «Fascismo».

Em conclusão, a nosso ver, o Marcelismo esteve sempre próximo de uma matriz de «terceira via» de tipo «corporativista», com traços da influência «fascista», e de uma visão «colonial» de encarar o território português. Marcello Caetano, devido à sua vivência familiar, lisboeta e pequeno-burguesa, mas bem próxima da grande burguesia, que representava o seu amigo Pedro Theotónio Pereira ${ }^{17}$ apesar da natural lógica "anti-burguesa» (em termos de mentalidade) do seu ideário inicial -, e às suas experiências de reflexão política como intelectual, jurista, professor e reitor, num mundo bem diferente dos anos trinta e quarenta, poderá ter tentado completar, actualizar e modernizar o regime, mas nunca o terá pretendido transformar. Pesem embora as ilusões de muitos e o significado que afinal acabou por ter essa «modernização» para a queda do próprio regime. Por outras palavras, o Marcello Caetano do Marcelismo, no final da década de sessenta e no início da década de setenta, não é muito diferente do Marcello Caetano dos decénios anteriores. O que se passou é que o «pragmatismo» e o «oportunismo» (em sentido politológico) puderam nele manifestar-se de modo diferente ao de Salazar, que governou o país noutro tempo, de 1932 a 1968, e que era mais velho do que Marcello cerca de 17 anos. No fundo, há um salazarismo-marcelista antes do Marcelismo ou um Marcelismo que deriva do salazarismo-marcelista. Rolão Preto não esqueceu, na referida "carta» a Marcello, o significado que teve a sua experiência universitária ${ }^{18}$ (digamos: fundamentalmente a sua experiência de professor de Direito, Direito Corporativo, Direito Administrativo e Direito Constitucional, e, depois, a sua experiência de reitor da Universidade da capital do país), pelo que esperou - ou disse «esperar» - a abertura de Marcelo ao pluripartidarismo. Poderia ser que, sequencialmente e em teoria, se pudesse ter verificado esse percurso. Mas, ele não era possível, na prática, em ambiente de "guerra colonial», e da insistência em manter incólume a posse do território ultramarino, pelo que a sua «Primavera» teria de ser sempre ilusória e acabaria, contraditoriamente, por impedir toda e qualquer abertura, com excepção daquela que não era de ordem política essencial e poderia parecer actualizar o regime. Essa actualização verificava-se pela via «popular» ou populista (recordemos a nova nomenclatura marcelista para a União Nacional - Acção Nacional Popular), ou por uma via mais «elitista»: na educação, numa fórmula ainda hesitante mas que tinha o sentido de «educação para todos", no aumento de regalias sociais para os cidadãos (daí o Estado mar-

17 Sobre a biografia de Pedro Theotónio Pereira, e das suas relações com Marcello Caetano, ver Fernando Manuel Santos Martins, Pedro Theotónio Pereira. Uma biografia (1902-1972). 2 vols. Dissertação de doutoramento apresentada na Universidade de Évora, 2004.

18 Cfr. Carta a Marcello Caetano cit., p. 4 
celista se chamar «Estado Social»), numa certa abertura controlada a uma «cultura europeia», mesmo no domínio da imprensa periódica (recordem-se os casos da Vida Mundial e do Expresso), no desenvolvimento económico possível - por oposição à imagem conservadora e agrária do regime de Salazar, que, no entanto, teve também momentos de afirmação desenvolvimentista, como seria próprio de um regime que se pretendeu tradicional mas «moderno», e personalidades que apontavam nesse sentido - e nas novas relações internacionais, que fazia esquecer a imagem pungente do «orgulhosamente sós» do discurso de Salazar de $1965^{19}$.

Em resumo, o que separa o Salazarismo do Marcelismo é - segundo a nossa interpretação e parafraseando, se nos é permitido, o título do filme de Terrence Malik - uma «fina linha vermelha» (ou «azul», se se entender mais apropriado) ${ }^{20}$, que difere mais pela «imagem urbana» do segundo do que pela realidade das intenções. Mas, para se perceber isso, será necessário conhecer um pouco melhor ou lembrar Marcello Caetano antes do Marcelismo. Fá-lo-emos apenas para apresentar uma hipótese de trabalho, a completar ou a suplementar outros ensaios já publicados, a ser infirmada ou confirmada.

\section{DO INTEGRALISMO À REPÚBLICA CORPORATIVA DE SALAZAR}

Na sua juventude - tinha Marcello Caetano 20 anos - tornou-se particularmente simbólica a publicação da revista, de que foi redactor-fundador com Albano Pereira Dias de Magalhães ${ }^{21}$, Ordem Nova, que tinha como subtítulo caracterizador o célebre epíteto de Revista Anti-Moderna, Anti-Liberal, Anti-Democrática, Anti-Burguesa e Anti-Bolchevista. Contra-Revolucionária; Reaccionária; Católica, Apostólica e Romana; Monárquica; Intolerante e Intransigente; Insolidária com Escritores, Jornalistas e Quaisquer Profissionais das Letras, das Artes e da Imprensa. ${ }^{22}$

O subtítulo é muito elucidativo. Marcello Caetano e os seus companheiros de luta afirmavam pertencer à «nova geração», à «geração reaccionária»" ${ }^{23}$, pelo que organizaram o Instituto de António Sardinha, que, por certo devido à sua radical acção contra-revolucionária, numa altura em que a Ditadura duvidava ainda acer-

19 «Erros e fracassos da era política», discurso proferido na posse da Comissão Executiva da União Nacional, em 18 de Fevereiro de 1965, in Oliveira Salazar, Discursos. 1959-1966. Coimbra, Coimbra Editora, 1967, vol. VI, p. 368.

20 The thin red line (1998) - o filme, que retoma um título clássico sobre a guerra, teve em português o nome de A barreira invisível. Trata-se de uma reflexão «filosófica» sobre a diferença ténue das possibilidades da paz, com todo o seu sentido paradisíaco, e as possibilidades da guerra, com toda a sua violência. A utilização desta imagem só se justifica pela riqueza do seu significado e pelo nosso constante interesse pelo cinema. É, no entanto, apenas uma extrapolação vocabular.

21 Ambos, com Pedro Theotónio Pereira, pertenceram à União Católica dos Estudantes Portugueses, organizada em Março - Abril de 1924 no Centro Académico de Democracia Cristã (CADC), de Coimbra.

22 Iniciada em Março de 1926 — antes, portanto, da depois chamada «Revolução Nacional» de 28 de Maio 1926 - teve o seu último número em Fevereiro de 1927, no qual se inseriu o «Índice do vol. $1 .{ }^{\circ}$

${ }^{23}$ Cfr. a nota de redacção do n. ${ }^{\circ} 3$, Maio de 1926 , p. 98 ss. 
ca do caminho a percorrer, foi encerrada ${ }^{24}$. A sua posição alinhava-se, pois, pelo Integralismo Lusitano, numa lógica de positivismo de direita, de neo-tomismo e de humanismo cristão, mas também, obviamente de antiliberalismo e de antibolchevismo, e contrário à maçonaria, em nome da Tradição, da Religião e da Moral. $\mathrm{O}$ objectivo seria, em primeiro lugar, criar um «núcleo central», uma «minoria inteligente e activa», após o que se poderia adoptar a fórmula maurrasiana: «Em primeiro lugar, a política» (Politique d'abord) ${ }^{25}$. No artigo inicial, de apresentação da revista, intitulado sintomaticamente «Anunciação», podia ler-se:

É também em nome do que é humano que nós nos proclamamos católicos e monárquicos, - colocados já nos dois termos da evolução espiritual da humanidade que acorda do sono profundo!

Monárquicos somos e bom é que claramente fique assente que o somos por uma forma integral e completa. Somos contra-revolucionários e vemos na reacção o único remédio para o nosso mal. Monárquicos, não nos contentemos com um Rei que reine e não governe, mas porque queremos um Rei que reine e tenha a obrigação de governar, um Rei que governe embora não administre, que seja verdadeiramente o chefe, chefe económico, chefe político, chefe nacional. Um Rei que, com o seu poder, concentrando, rodeado pelas suas elites, assistido pelos conselhos técnicos, aconselhado pelas Cortes-gerais, seja, parafraseando a frase de Maurras - o chefe das repúblicas portuguesas. ${ }^{26}$

Marcello Caetano e os seus camaradas aderiam à Ditadura, mas como fórmula «transitória», não se deixando entusiasmar demais com os exemplos vindos de Espanha ou de Itália. «Não nos deixemos iludir pelos exemplos do estrangeiro; na Espanha e na Itália há ditadores, é certo, mas há um rei. Um rei que é a garantia da continuidade da obra encetada, um rei que substituirá inteligentemente o ditador que está quando este por qualquer motivo tiver que deixar o poder, um rei que encarna o interesse nacional»27. Portanto, a «adesão» da Ordem Nova à «República», sob a forma ditatorial, era apenas «um certo tipo de adesão», pois as suas ideias apontavam sim para um sistema que tinha como base toda uma concepção monárquica tradicionalista ou neo-tradicionalista. Poderiam os seus redactores, como Leão Ramos Ascenção (na polémica com Raúl Proença), aceitar o fascismo italiano como modelo, nomeadamente na devolução ao Estado da Autoridade, mas, numa lógica recorrente (que só em parte, salientemos nós, tem origem em palavras de Mussolini, como era alegado), entendiam que o caso italiano não se poderia transferiir ${ }^{28}$. Podiam outros, como Pedro Theotónio Pereira, criticando a "democracia e toda a sua miragem grosseira» em defesa do "Progresso", citar

24 Cfr. Ordem Nova, n. ${ }^{\circ} 12$, Fevereiro 1927, p. 392.

25 Nota de redacção assinada por Marcello Caetano, «As directrizes da "Ordem Nova" », in n. ${ }^{\circ}$, Março de 1926, pp. 35-37.

26 Marcello Caetano, «Anunciação», in revista cit., n. ${ }^{\circ}$ 1, Março de 1926, pp. 11-12.

27 Marcello Caetano, «A nossa "adesão"», in revista cit., n. ${ }^{\circ}$ 5, Junho-Julho de 1926, p. 148.

28 Cfr. O fascismo, o anti-fascismo e a Monarquia hereditária, Coimbra, Imprensa Académica/Junta Escolar de Coimbra do Integralismo Lusitano, 1926, p. 5. A redacção deu todo o apoio ao seu correligionário, citando o seu opúsculo na Ordem Nova («A ditadura», n. ${ }^{3}$, Maio de 1926, p. 98). 
Mussolini e a afirmação de «liberdades» em oposição à ideia de Liberdade ${ }^{29}$, mas, acima de tudo, o que desejavam era menos defender o fascismo de Itália do que, mais amplamente, «o conceito novo de Estado» ${ }^{30}$. Podia ainda o próprio Marcello Caetano elogiar a Italia rinovata e «a energia do duce» ao limpar o país dos «intelectuais» que iam buscar a França as doutrinas deletérias, a França "onde nem os melhores se entendem e onde todos se corrompem», mas essa teoria contra os «jornalistas e quaisquer profissionais das letras, das artes e da imprensa» tinha apenas como objectivo criar em Portugal uma "ordem nova», assente na Tradição, estruturada como uma Monarquia integral, de origem portuguesa ${ }^{31}$. Podia o mesmo Caetano - ele que era um jurista em formação tomar posição contra as «preocupações legalistas» dos juristas relativamente à ditadura em nome da Constituição de 1911, mas a sua «adesão» à ditadura militar era apenas considerada como uma atitude «revolucionária» que daria origem a um «Novo Estado» de tipo monárquico tradicional e orgânico ${ }^{32}$.

Nesta busca de um ideal, de uma monarquia integral (Caetano fora também secretário de redacção da Nação Portuguesa e foi redactor do diário monárquico Ideia Naciona), havia, pois, como em todos os políticos das «novas gerações», uma lógica pragmática e «oportunista», diferente da lógica alegadamente «idealista» de liberais e democratas (mesmo que, pessoalmente, alguns se pudessem enterrar no mais vil oportunismo). E essa lógica será levada às suas consequências, ao contrário da atitude de (outra) "coerência» tomada por alguns integralistas e nacionais-sindicalistas, como Rolão Preto, que recusaram o Salazarismo. Deste modo, licenciado em Direito em 1927 pela Universidade de Lisboa, já se encontra em 1929 a colaborar com Salazar como auditor jurídico do Ministério das Finanças, em 1931 já integra a Comissão Executiva da União Nacional e no ano seguinte terá um papel de relevo na redacção do projecto da futura Constituição do Estado $\mathrm{Novo}^{33}$, ou seja, na Constituição que consagra, no seu artigo $5 .^{\circ}$, o sistema de Salazar como uma «República unitária e corporativa».

${ }^{29}$ Pedro Theotónio Pereira, «A alavanca do Progresso», revista cit., n. ${ }^{\circ}$, Setembro de 1926, p. 204.

30 Idem, p. 210.

31 "A chaga da literatice», revista cit., n. ${ }^{\circ}$ 9-10, Novembro - Dezembro de 1926, pp. 267-271. Sobre a Itália, ver p. 268. Esta posição contra os «intelectuais» é comum, não só na revista Ordem Nova como na crítica literária que manteve no jornal Ideia Nacional. Por exemplo, apoiou — no seu dizer - a «cremação daquela papelada imunda que inunda a cidade», concretamente as Canções, de António Botto, Sodoma Divinizada, de Raúl Leal, ou Decadência, de Judith Teixeira. A «cremação" pode ter sido um exagero, em relação ao que se passara de facto (segundo o testemunho de Theotónio Pereira; que participara nessa acção), mas, de qualquer modo, era bastante simbólica a utilização da palavra. Também Marcello Caetano criticara Raul Brandão, não só a sua peça $O$ Gebo e a Sombra, mas também a que foi considerada a sua obra-prima Humus: «O Humus, em qualquer país civilizado, seria um documento decisivo para um processo de interdição por demência».

32 «Preocupações legalistas», revista cit., n. ${ }^{\circ} 11$, Janeiro de 1927, pp. 345-350.

${ }^{33}$ Sobre estes e outros aspectos da vida de Marcello Caetano, naturalmente com a respectiva interpretação, ver Fernando Rosas, entrada "Caetano, Marcello José das Neves Caetano (1906-1980)», in Fernando Rosas e J. M. Brandão de Brito, Dicionário de História do Estado Novo, Lisboa, Círculo de Leitores, 1996, vol. I, p. 110, Vasco Pulido Valente, entrada "Caetano, Marcello José das Neves Caetano (Lisboa, 17-8-1906 - Rio de Janeiro, 26-10-1980)", in António Barreto e Maria Filomena Mónica (Coord.), Dicionário de História de Portugal, Suplemento, Lisboa - Porto, Figueirinhas, 1999, vol. I, 
Mas, não se vai ficar por aqui o seu pragmatismo. Marcello vai — como se disse e ele próprio atesta nas suas Memórias - justificar a manutenção do regime republicano nos meios políticos (era então presidente da Câmara Corporativa), por altura da revisão constitucional, a partir de Abril de 1951 e concretizada em Junho seguinte ${ }^{34}$, da morte de Carmona em 18 desse mesmo mês de Abril, e especialmente no Congresso da União Nacional de 1951, no seu discurso de 23 de Novembro, conhecido por «discurso de Coimbra» ${ }^{35}$. E a sua justificação terá como sempre a argúcia de uma reflexão histórica de tipo pragmático, em que recorre mesmo a um texto anterior - aquele que vimos na Ordem Nova sobre a sua «adesão» à Ditadura - para alterar a sua posição. Para ele, o Estado Novo era verdadeiramente «um regime», ou seja, "um sistema de regras institucionais» que permitia «a regularidade do governo da Nação». Portanto, a obra de Salazar, «Mestre» e "Chefe», não se reduzia à sua vida, nem o sistema seria fraco por ser de tipo republicano, mesmo que as suas conviç̧ões pessoais o impelissem, naturalmente, para a "restauração monárquica», dado que, como afirmara anos atrás, «as ditaduras só podiam alcançar sentido nacional quando apoiadas no espírito de continuidade e na consciência da responsabilidade dinástica de um monarca». O que the parecia agora é que tudo evoluíra e teria de concluir que oitenta anos de Monarquia constitucional - «república coroada» - acabara por quebrar a tradição monárquica portuguesa. Por outro lado, a história estava - a seu ver - a gerar «novos regimes de governo", que não se confinavam à classificação clássica em «regimes de chefe de Estado hereditário» (monarquias) e «regimes de chefe de Estado electivo» (repúblicas). Além disso, era preciso ter presente que «a monarquia não é só um chefe de Estado vitalício e hereditário»: «este tem de corresponder ao remate de toda uma organização social e política, sem a qual a contradição das instituições torna, inevitavelmente, precária a posição do monarca». De onde concluía, pensando no Estado Novo de Salazar, cujas qualidades havia elogiado, logo no início do discurso: «o comando único — o comando de um só apoiado no sentimento e na vontade da nação, cujos anseios profundos e legítimas aspirações interpreta, exprime e realiza, essa é que é a forma que o novo tipo de Estado solicita, para poder corresponder à extensão e profundidade das tarefas que os homens esperam».

Habilmente, António Sardinha é citado no princípio do seu discurso e é com ele que termina. Simples referências sem grande significado, apenas para marcar a sua ligação originariamente monárquica... O mais importante é afinal a constatação do seu próprio pragmatismo, o pragmatismo, de tipo inglês, da «lógica polí-

pp. 198-216, Joaquim Vieira, Marcello Caetano. Fotobiografias do Século xx. Lisboa, Círculo de Leitores, 2002. É também muito importante conhecer a obra citada Minhas Memórias de Salazar, em que Marcello dá testemunho da sua vida.

${ }^{34}$ A alteração da Constituição de 1933, formalizada pela lei da Assembleia Nacional de 11 de Junho de 1951, limita-se, neste particular, a confirmar a estrutura «republicana» do Estado.

${ }^{35}$ Cfr. Minhas Memórias de Salazar, p. 361 ss. Deve dizer-se que desde os finais dos anos quarenta que Marcello apresentava essa opinião, que justificava a sua defesa da candidatura de Salazar para Presidente da República (ob. cit., por exemplo, p.320). 
tica»: «a lógica política é uma lógica pragmática: são os resultados que fornecem o critério de julgamento da exactidão. É pelos frutos que se distinguem as boas árvores das más». ${ }^{36}$

A posição política de Marcello Caetano consiste, pois, na defesa de um regime que, sendo uma «República», tem um conteúdo político - baseado na Autoridade do Chefe - e «social» de tipo corporativo. Se o corporativismo tinha na filosofia integralista, de todas as gerações, a começar na que foi exposta na revista Nação Portuguesa, uma grande importância, o certo é que o corporativismo que foi defendido por Marcello Caetano haveria de ter um sentido próprio, motivado por outras influências que foram entretanto surgindo depois de 1914 (data do início da publicação da revista referida) ou de 1926 (data da publicação da Ordem Nova).

Marcello foi, sem dúvida, um dos mais fervorosos e consequentes corporativistas do regime, a ponto de não ter aceite a criação do Ministério das Corporações ${ }^{37}$ exactamente porque entendia que um «sistema corporativo" não deveria ter no governo um ministério que actuasse naquilo que constituía a sua própria essência e porque, deste modo, todos os ministérios deveriam exercer afinal uma acção corporativa ${ }^{38}$. Por outro lado, e isso teria sido uma das causas das suas tão propaladas dissensões com Salazar, entendia que o corporativismo era uma realidade sempre incompleta e imperfeita. Sabe-se, de resto, como ele e o seu amigo Pedro Theotónio Pereira, o primeiro subsecretário das Corporações e Previdência Social ${ }^{39}$ (cargo que Marcello parece não ter querido aceitar, por razões ligadas à carreira universitária ${ }^{40}$ ), pretendiam apressar todo o sistema de reformas tendentes à constituição do "Estado Corporativo", que era para eles uma questão fundamental do regime. E conhece-se o desassombro de Marcello ao enviar cartas a Salazar, por exemplo em 1943 ou em 1944, criticando o facto de o corporativismo não avançar no seu processo de organização, o que originava grande descontentamento entre os vários grupos profissionais ${ }^{41}$.

Logo em 1935 publicava o seu manual Lições de Direito Corporativo. Nele afirmava peremptoriamente que não havia ainda em Portugal Estado Corporativo ${ }^{42}$, mas continuava a dizer o mesmo ao longo do tempo, mesmo em 1950, quando proferiu uma conferência, no dia 23 de Março, no Gabinete de Estudos Corporati-

${ }^{36}$ Cfr. este discurso (supomos em versão integral) - que não se encontra publicado nas actas do Congresso - in Diário de Notícias, 24 de Novembro de 1951.

${ }_{37}$ Criado pelo decreto-lei n. ${ }^{\circ} 37909$, de 1 de Agosto de 1950, tendo sido José Soares da Fonseca o primeiro titular da pasta.

38 Minhas Memórias, p. 345.

39 Foi empossado logo no dia da promulgação da Constituição de 1933, 11 de Abril de 1933.

40 Segundo nos diz nas suas Memórias, esse teria sido o convite «mais honroso», pois tinha apenas 26 anos. Estava - segundo acrescentava - «à beira de prestar provas de concurso para Professor da Faculdade de Direito de Lisboa, com dissertação impressa e data marcada» (Memórias cits., p. 58).

${ }_{41}$ Ver, por exemplo, cartas a Salazar de Novembro ou Dezembro de 1943 e de 10 de Fevereiro de 1944, in José Freire Antunes, Salazar e Caetano. Cartas secretas. 1932-1968, Lisboa, Círculo de Leitores, 1993, pp. 116 e 118-119.

42 Lições de Direito Corporativo, Lisboa, 1935, p. 148. 
vos, intitulada Posição actual do corporativismo português ${ }^{43}$. Marcello Caetano desde os anos trinta, portanto, procurava conhecer o corporativismo e as origens do corporativismo português, e dar-lhe um sentido, através da acção.

Assim, num outro estudo, de 1938, que intitula O Sistema Corporativo ${ }^{44}$, afirma a origem divergente e convergente, longínqua e próxima, do nosso corporativismo, radicando-o nas corporações medievais, no corporativismo católico, nomeadamente nas teses das encíclicas de Leão XIII e Pio XI, com origens no pensamento tomista, mas também no Integralismo Lusitano (destaca, neste caso, o nome de Pequito Rebelo) e até nas teorias dos tradicionalistas do século XIX, nomeadamente José da Gama e Castro. Mas não omite a experiência do corporativismo fascista de carácter eminentemente legislativo (em cuja produção salienta a Carta del Lavoro), ainda que tivesse um património doutrinário inicial formado por correntes socialistas e sindicalistas francesas e italianas, em que nomeia o pensamento de George Sorel, Charles Péguy e Hubert Lagardelle e o grupo de Olivetti e Orano, a que pertencia Mussolini, o que levou a uma concepção de Estado «totalitário», em que toda a vida social se integrava no Estado. Indo mais longe nas suas reflexões sobre as origens do "corporativismo moderno", radica-o ainda na escola do "corporativismo integral e puro» do sociólogo austríaco Othmar Spann (em parte inspirado na escola de «economia nacional» de Frederich List) e do romeno Mihail Manoilesco. E fala ainda das teses do neo-socialismo de Marcel Déat e de Henri de Man ${ }^{45}$.

Nessa mesmo obra - talvez das mais importantes sobre a esta matéria em termos de ideologia - Marcello Caetano, para além de fazer reflexões específicas sobre a sociologia e a economia corporativas, aborda directamente a questão de o «Estado Corporativo». Não diferem as suas teses, substancialmente, das concepções de Salazar, ainda que tenham um cunho mais teórico (Salazar apenas deixou a sua marca na legislação que produziu, ou que possibilitou que fosse produzida, e em algumas afirmações dos seus discursos). Para ele, o Estado, «Nação organizada", tem uma acepção centralizada e descentralizada, o que corresponde na concepção do Integralismo Lusitano, em que Marcello bebeu e continuava a beber, à «tendência concentradora» e à «tendência descentralizadora». Por isso, segundo o seu entendimento, não seria muito correcto falar de «Estado Corporativo», que só aceita por razões de prática e por fortes motivos constitucionais, pois é assim que concebe o Estado a Constituição de 1933, no seu artigo 5.. A «designação apropriada» seria «Estado orgânico ou Estado integralista».

De acordo com a teoria de Marcello Caetano, as autarquias locais (recordemos a importância dos seus estudos sobre o municipalismo), os institutos públicos e as corporações devem ser considerados entidades autónomas, não devendo as corporações propriamente ditas ser entendidas como fonte directa do poder político.

43 Posição actual do corporativismo português, Lisboa, Império, 1950, p. 12.

44 O Sistema Corporativo, Lisboa, s. ed., 1938

45 Ob. cit., p. 21 ss. Em relação a Mihail Manoilesco cita a sua célebre obra, muito divulgada em Portugal, Le siècle du corporatisme: doctrine du corporatisme intégral et pur, Paris, Félix Alcan, 1934 
Nesta perspectiva, Marcello colocava-se num terreno de "corporativismo misto", ou seja, nem na acepção do «corporativismo puro», em que as corporações e o seu parlamento eram entendidas como os únicos órgão de poder legislativo supremo, nem na acepção do "corporativismo subordinado", em que o «parlamento corporativo" não tinha qualquer poder legislativo, que seria atribuído a uma assembleia saída do sufrágio universal ou emanada de um partido único constitucional. Para ele, o poder legislativo era repartido por um órgão corporativo e por uma "Câmara democrática», a que dá um sentido muito próprio em termos de «eleição», conforme veremos. Mas esse órgão corporativo não tinha um papel reduzido, ao contrário do que se poderia dizer, pois é muito importante o seu papel de natureza técnica e consultiva. Por outro lado, a Assembleia Nacional não tinha um sentido demasiado extenso na ordem legislativa. Segundo afirma de forma expressiva, com frases em itálico: «a Assembleia Nacional só terá competência legislativa para estabelecer as bases do regime jurídico das instituições fundamentais, e deve exercer, sobretudo, uma real e efectiva fiscalização da forma como o Governo e as corporações respeitam e servem o ideal nacional e os interesses sagrados das pessoas".

Nesta ordem de equilíbrio de forças, e por isso Marcello Caetano - no contexto da sua formação - preferia a designação de «Estado orgânico ou integralista» à de "Estado Corporativo», o governo deveria ter uma capacidade de intervenção na actividade corporativa, vigiando ou reprimindo para que as «leis gerais» e as «leis corporativas» definissem e garantissem os direitos e deveres das pessoas singulares e das pessoas morais. Terá sido esta lógica corporativista idealista, que recusa um «regime de polícia» e considera o «poder arbitrário [...] uma anomalia forçosamente transitória», que levou Marcello Caetano por vezes a tomar posição desassombrada contra certos excessos repressivos no tempo de Salazar e no seu próprio governo. Mas, deve dizer-se que também a sua lógica supunha ambiguidades e contradições, que na prática haveriam de vir ao de cimo no seu governo dos anos sessenta e setenta.

Só para compreendermos completamente a estrutura do «Estado Corporativo» que defende, fazendo assim a sua leitura da Constituição, que havia ajudado a redigir, vejamos agora como entende algo de muito importante, ou seja, o fenómeno da «eleição». Se repudia como «fonte do poder político» as corporações, veremos que também não aceita - o que seria, de resto, uma contradição ideológica fundamental - o «sufrágio universal» como escolha livre, numa concepção demoliberal, quer para o Presidente da República quer para a Assembleia Nacional. Mas leiamos o próprio texto de Marcello Caetano, influenciado, neste particular, pela obra de Manoilesco sobre 0 «partido único»46:

Mas se a fonte do poder político no Estado corporativo não são as corporações, onde buscá-lo então? Não pode admitir-se a eleição democrática pelo

${ }^{46}$ Le parti unique. 3. $^{\mathrm{a}}$ ed.. Paris, Imp. de Lagny, Emmanuel Grevin et Fils, 1937. 
sufrágio universal, porque isso seria subordinar a sociedade ao indivíduo, sufocar a ordem nova nos defeitos dos sistemas falidos. A função política, à qual compete a orientação espiritual da Nação para os seus destinos, deve pertencer a um escol de cidadãos seleccionados pelo sacrifício, pelo espírito de renúncia e pela devoção ao bem comum, em cujas almas impere "o sentido ascético e militar da vida». Esse escol, colocando acima da consciência dos seus direitos o cumprimento dos deveres para com a Pátria, animado pela mística do interesse nacional, e suprimindo divergências acidentais para só acentuar a comunhão dos princípios na unidade dos fins, forma o partido único. Assim caracterizado funcionalmente, pode dizer-se que o partido único é a corporação nacional da política.

Ao partido único deve pertencer a indicação da assembleia legislativa e do Chefe do Estado, quando este não seja hereditário ${ }^{47}$. É no partido único que o Chefe do Estado deve procurar o grupo de homens que hão-de constituir o Governo, órgão superior de direcção de todas as actividades nacionais, gestor supremo dos serviços públicos. A sanção plebiscitária do nome escolhido para a chefia do Estado, nos regimes republicanos, não significa neste caso eleição, mas adesão. Por isso se compreende que não haja liberdade de apresentação de candidaturas, nem se contem os votos que não recaiam na lista única ${ }^{48}$

Pode dizer-se que o processo de desenvolvimento do «Estado Novo» de Salazar e do «Estado Social» de Marcello Caetano seguiu basicamente estas ideias.

Salazar também tomou uma posição idêntica, como dissemos mais na prática, mas também em alguns dos seus discursos. Assim, por exemplo, numa reflexão significativa (em discurso de 9 de Dezembro de 1934), na qual punha em causa o papel das assembleias legislativas, procurava, todavia, prevenir-se contra o «erro» de extinguir de vez com assembleias políticas, discutindo assim a intenção de Mussolini de dissolver a Câmara de Deputados passando a competência legislativa para o Conselho Geral das Corporações ${ }^{49}$, o que só se veio a verificar mais tarde, em 1939. Portanto, também ele, evidentemente, não se integrava numa corrente de «corporativismo puro». E, por sua vez, são por demais conhecidas as suas posições contra o sufrágio universal. Mas, só para vermos como sempre se manteve ligado a esse princípio, vejamos este passo da entrevista dada a Serge Groussard, do jornal parisiense de direita Le Figaro, já no final dos anos cinquenta:

Não creio no sufrágio universal, porque o voto individual não tem em conta a diferenciação humana. Não creio na igualdade, mas na hierarquia. Os homens, na minha opinião, devem ser iguais perante a lei, mas considero perigoso atribuir a todos os mesmos direitos políticos.

Se o liberalismo consiste em construir toda a sociedade sobre as liberdades individuais, então eu considero mentira o liberalismo. Não creio na liberdade, mas

47 Pensava Marcello, obviamente, no caso da Monarquia italiana e de outras monarquias, mas, acima de tudo, ainda desejava que tal se viesse a verificar numa Monarquia portuguesa, marcada por uma lógica integralista e não demoliberal, como fora a Monarquia Constitucional caída em 1910.

48 O Sistema Corporativo, pp. 51-52.

49 «A constituição das Câmaras na evolução da política portuguesa», discurso radiodifundido da União Nacional, em 9 de Dezembro de 1934, para as sessões de propaganda realizadas em todo o país, in Salazar, Discursos, vol. I, pp. 381-382. 
nas liberdades. A liberdade que não se inclina perante o interesse nacional chamase anarquia e destruirá a nação. ${ }^{50}$

Por sua vez, recorde-se, para melhor entender a posição de Marcello Caetano em 1938, que, se a eleição para presidente da República contou com candidatos da oposição a partir de 1949, não poderiam, de acordo expressamente com lei de revisão constitucional de 1951, concorrer se não oferecessem «garantias de respeito e fidelidade aos princípios fundamentais da ordem política e social consignada na Constituição " ${ }^{51}$, o que levou ao afastamento, nesse ano, do candidato Rui Luís Gomes, e só em 1958 um candidato se abalançou a ir às urnas, o general Humberto Delgado, que fora um dos apoiantes do Estado Novo no início do regime. Posto isto, a Constituição foi outra vez alterada em 1959, passando o Chefe de Estado a ser votado, indirecta e «corporativamente», por um colégio eleitoral (lei 2100, de 29 de Agosto, artigo 72..$^{52}$, o que, obviamente, não foi alterado na última revisão da nossa lei fundamental, no tempo do Marcelismo, em 1971 (lei n. ${ }^{\circ}$ 3/71, de 16 de Agosto). De acordo com as ideias de Marcello - como de Salazar - só se entenderia a «eleição» do Presidente da Republica em termos de «adesão» a uma proposta do «partido único» (designação que Salazar e muitos salazaristas não empregaram). E o mesmo se pensava, afinal, das «eleições» para a Assembleia Nacional, a que os oposicionistas só deram verdadeira importância depois das citadas modificações produzidas no respeitante às «eleições» para o Chefe do Estado, em 1959.

Fundamentalmente o que - como já se aludiu — originava as discordância de Marcello Caetano relativamente a Salazar era uma questão de prática, ou do ritmo com que se verificavam as reformas. Por isso esteve sempre presente em Marcello a ideia de que o «Estado Corporativo» não estava ainda construído. $\mathrm{Na}$ verdade, a criação de Corporações, ou seja, as organizações corporativas de cúpula, com a presença de operários e patrões, numa lógica de entendimento mútuo, que desempenhavam a mesma função nacional, no âmbito económico ou económico-cultural e no âmbito cultural e moral, só foram constituídas nos anos cinquenta (através da lei n. 2 086, de 22 de Agosto de 1956), supostamente autónomas da intervenção estatal, o que só em teoria sucedia ${ }^{53}$. E será o próprio Marcello Caetano, como presidente do Conselho, ainda a modificar algumas das instituições corporativas ${ }^{54}$, num tempo em já não era possível nem fazer com eficácia nem (por via interna) desfazer um Estado que não tinha mais hipóteses de subsistir. Seja como for, ao longo do seu mandato de seis anos continuava a falar do Estado Corporativo.

50 Tradução da entrevista publicada no Le Figaro, em 2 e 3 de Setembro de 1958, in António de Oliveira Salazar, Discursos, vol. VI, Coimbra, Coimbra Editora, 1958. p. 41.

51 Cfr. lei n. 2 048, de 11 de Junho de 1951, artigo $73 .^{\circ}, \S 1 . .^{\circ}$

52 Ver lei n. ${ }^{\circ} 2100$, de 29 de Agosto de 1959, artigo 7.', que altera o artigo $72 .^{\circ}$ da Constituição.

53 Cfr. Manuel de Lucena, A evolução do sistema corporativo português, tomo I, O Salazarismo, Lisboa, Perspectivas \& Realidades, 1976, p. 316 ss.

54 Ver Manuel de Lucena, ob. cit., tomo II, O Marcelismo, Lisboa, Perspectivas \& Realidades, 1976. 


\section{O «EDUCADOR» E A CONCEPÇÃO DA MOCIDADE PORTUGUESA COMO «ESCOLA DE DIRIGENTES»}

Parece indiscutível que Marcello Caetano interpretou, como professor e como reitor, uma lógica de diálogo. Nos anos quarenta publicou alguns textos que se aproximavam de uma ideia «nova» de Universidade, em termos pedagógico-didácticos, no âmbito do ensino e da investigação cientifica. Para além de outros, uma separata dos Estudos do CADC, de Coimbra, intitulada sintomaticamente Universidade Nova. O problema das relações entre professores e estudantes ${ }^{55}$, publicada em 1942, que, a par de obras de autores de ideologia diferente, como Ortega y Gasset, Celestino da Costa, Afonso Botelho, Orlando Ribeiro, Fernando de Aguiar, era apresentada como obra para ser lida pelos estudantes católicos como processo preparatório do I Congresso Nacional da Juventude Universitária Católica (JUC), de $1953^{56}$, congresso esse que representou, verdadeiramente, a primeira afirmação de abertura associativa dos estudantes «católicos» a novas concepções político-sociais. Mas, não devemos esquecer que Marcello Caetano, na altura da publicação da referida separata, era também Comissário Nacional da Mocidade Portuguesa (MP), sucedendo ao germanófilo engenheiro Francisco Nobre Guedes, que havia seguido para Berlim como embaixador. Portanto, não há, nem poderia haver, verdadeira contradição entre o que parece dizer de mais «liberal» e «actual» em alguns textos universitários e outros dedicados à organização da juventude nacionalista instituída em 1936, tendo como modelo a Opera Nazionale Balilla ${ }^{57}$.

Com efeito, se lermos os discursos por ele proferidos nos anos quarenta, como Comissário Nacional da MP, por exemplo aqueles que foram compendiados na obra Por Amor da Juventude, em 1944, ficamos com a ideia de que o escotista dos tempos de juventude, que fazia elogios a Baden Powell ${ }^{58}$, vivia a MP como uma grande chama nacionalista e épica, à maneira da organização congénere italiana. Assim, nesses seus discursos surgem os «heróis da Pátria» — os heróis da fidelidade à palavra dada, como o alcaide de Coimbra Martim de Freitas, ou os heróis que morrem por uma causa, como Duarte de Almeida «O Decepado», os herói dos Descobrimentos e do Império, como o Infante D. Henrique ou D. João de Castro, o incontornável soldado da independência de Portugal Nun'Ávares Pereira, os heróis da Restauração (tema que desde os tempos da sua mocidade era objecto das suas conferências ${ }^{59}$ e que continuou a incendiar o seu entusiasmo nos

55 Já citado atrás, na nota 14.

56 Ver I Congresso da Juventude Universitária. Boletim de Informação, n. ${ }^{\circ}$ 3, 3 de Dezembro de 1953, s/ página, título «Prepara-te para o Congresso, lendo...».

57 Balilla era o nome da figura lendária de um jovem genovês que, em 1746, morreu numa revolta anti-austríaca.

58 Cfr. «Mousinho, capitão da Mocidade. Discurso pronunciado junto da campa de Mousinho de Albuquerque, na cerimónia comemorativa de Chaimite, em 28 de Dezembro de 1940», in Por Amor da Juventude, Lisboa, s. ed., 1944, p. 80.

59 Ver o discurso pronunciado no dia 1 de Dezembro de 1927 na sede da Juventude Católica de Lisboa, intitulado «A Restauração de Portugal», in Ordem Nova, n. 9-10, Novembro-Dezembro de 1927, p. 303 ss. 
discursos de 1 de Dezembro, dia da MP), os heróis da África, Mouzinho de Albuquerque ou João Azevedo Coutinho... Surgem, por outro lado, os «Balillas portugueses» (a expressão é nossa) que morrem pela Pátria ou a pensar na Pátria como o João Maurício, criança de oito anos que morre a cantar o hino da MP e que vai a enterrar envolto na sua bandeira ${ }^{60}$. Ou surgem os poemas nacionalistas, como aquele que já se publicava em 1934 numa obra «revolucionária de direita», do tempo da Acção Escolar Vanguarda ${ }^{61}$, da autoria de Guerra Junqueiro, o poeta da República, tão aproveitado pelo Estado Novo, e que, pelo seu significado (a temática da crise e da renascença e da morte pela Pátria), vamos transcrever:

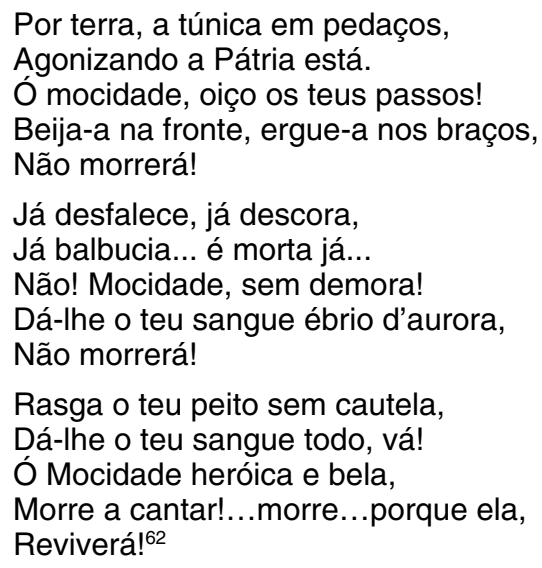

Continuando a nossa análise, diremos que Marcello afirmava, num óbvio espírito nacionalista de «originalidade» (sempre proclamada por Salazar para o seu regime), que a MP tinha uma «inconfundível personalidade» entre as organizações da mocidade do mundo ${ }^{63}$. Ela defendia, no seu dizer, a "Civilização Cristã» e a independência nacional. Por isso, como afirmava no prefácio da obra, repetindo as afirmações basilares de um discurso preferido em Outubro de 1943:

«A causa da Mocidade Portuguesa é a causa de Portugal!» «Ser contra a Mocidade Portuguesa é ser contra Portugal!» 64

À sua maneira, a MP era «revolucionária»: era contra o egoísmo, em prol da «justiça social», na luta pela «vitória sobre os inimigos da Pátria» ${ }^{65}$. A MP era, as-

60 Cfr. «A Mocidade não pára! Discurso pronunciado na cidade de Vila Real em 27 de Maio de 1943», in Por Amor da Juventude, p. 48.

61 O Problema Universitário em Portugal, Editorial Vanguarda, Avenida da Liberdade, 3-2. ${ }^{\circ}$ Lisboa, 1934, p. 38.

62 «As lições do $1 .^{\circ}$ de Dezembro. Discurso proferido no $1 .^{\circ}$ de Dezembro de 1940 da janela principal do Palácio da Independência», in Por Amor da Juventude, pp. 65-66. Ver Guerra Junqueiro, «À Mocidade das Escolas», in Finis Patriae (1890).

${ }^{63}$ Cfr. o discurso citado «A Mocidade não pára», in ob. cit., p. 35.

64 Ob. cit., p. 17.

65 Cfr. «Castelos de almas. Alocução proferida no acto da imposição das insígnias aos alunos do $8 .^{\circ}$ curso de Comandantes de Castelo da Escola Central de Graduados — Maio de 1941 », in ob. cit., pp. 130-131. 
sim, uma escola de elites, de dirigentes, conforme dizia Marcello nos seus discur$\operatorname{sos}^{66}$, desenvolvendo o tema num livro com várias edições, $A$ missão dos dirigentes, publicado pela primeira vez em 1942 e pela última em $1966^{67}$. Ali se falava do "espírito heróico contra o espírito burguês», como súmula de todos os princípios da «revolução» (entre os quais destacamos a «unidade nacional contra o espírito de partido ou de classe» e «a disciplina e a lealdade ao Chefe contra a desordem de um Estado acéfalo e de mil opiniões diversas» ${ }^{68}$. Seria dentro destes princípios que se poderia e deveria criar uma "geração nova», bem diferente, porém, no conteúdo do vocabulário vulgarmente usado. Vejamos este texto e, através dele, poderíamos recordar as suas lutas e dos seus companheiros (como Theotónio Pereira ${ }^{69}$ ) em prol da moral:

Dentro destes princípios é que poderemos criar uma nova geração portuguesa.

Quantas vezes se fala nas novas gerações sem que a expressão tenha sentido algum!

Gerações novas porque são as mais recentes, - mas velhas, velhíssimas no espírito, nos hábitos e nos costumes.

Gerações sem grandeza, sem ideal, sem elevação, — apegadas à tristeza do fado $^{70}$, ao vicio da crítica, ao ambiente do café, à descrença mórbida e às doenças venéreas.

Gerações para quem a sífilis é uma glória e a caspa uma condecoração, e cultivam com os mesmos cuidados o comunismo ou liberalismo e a dispepsia.

A geração nova que nós temos de criar há-de separar-se do passado pela vontade enérgica de vencer, pela serenidade de ânimo na adversidade ou nas simples contrariedades, e pelo idealismo puro servido por virtudes positivas e práticas. ${ }^{71}$

Portanto, até quase à sua ascensão à presidência do governo, Marcello Caetano mantinha as palavras dos anos quarenta e a sua fé numa "geração nova", de que fizera parte nos já recuados anos vinte. Mantinha, pois, o mesmo «espírito revolucionário de direita», que, no fundo, apesar de alguma liberalidade, não alteraria nos anos da Presidência do Conselho. Também a sua ideia de «Império»

66 Ver, para além dos discurso anterior, o texto «Grandeza e responsabilidade da missão do graduado. Alocução proferida na cerimónia da entrega das insígnias ao VII Curso de Comandantes de Castelo da Escola Central de Graduados em Agosto de 1940», in ob. cit., sobretudo p. 116.

${ }_{67}$ A missão dos dirigentes: reflexões \& directivas. Ed. do Comissário Nacional da Mocidade Portuguesa, Lisboa, Mocidade Portuguesa, 1942. A última edição (4. ${ }^{a}$ edição) e as anteriores têm o título $A$ Missão dos Dirigentes: Reflexões e Directivas sobre a Mocidade Portuguesa. Utilizámos a 3. ${ }^{a}$ edição, de 1952.

68 A Missão dos Dirigentes: Reflexões e Directivas sobre a Mocidade Portuguesa, pp. 14-15.

69 Ver a citada tese sobre Theotónio Pereira, de Fernando Manuel Santos Martins, Pedro Theotónio Pereira. Uma biografia (1902-1972), cap. II, «...uma cruzada de salvação pública», p. 83 ss.

70 Note-se esta desvalorização do fado, muito comum entre a direita, e não só, que vemos também nas páginas da Ordem Nova, pela pena de Ribeiro da Silva: «Guerra ao fado», in revista cit., n. ${ }^{\circ}$, Agosto de 1926, pp. 219-221.

71 A Missão dos Dirigentes, «Preparemos uma Geração Nova!», p. 16. 
- a missão dos graduados deveria estar "ao serviço do Império", como dizia num discurso de Agosto de $1943^{72}$ - não se alteraria, afinal, tanto, como poderia parecer. Mas, o que pensava realmente Marcello Caetano das «colónias» ou "províncias ultramarinas», que constituíram o seu grande problema nos anos sessenta e setenta?

\section{A QUESTÃO ULTRAMARINA}

$\mathrm{Na}$ abertura da campanha eleitoral para Assembleia Nacional, Marcello Caetano, num discurso proferido em 15 de Setembro de 1969, propôs aos portugueses duas opções consideradas fundamentais: a de rejeitar o abandono do Ultramar, optando por uma política de progressivo desenvolvimento e de crescente autonomia; e a implementação de reformas, com firmeza, mas também com respeito pela ordem pública e pela paz social, recusando a turbulência revolucionária ${ }^{73}$. Quanto à questão ultramarina, a lei n. ${ }^{\circ}$ 3/71, de 16 de Agosto, de revisão constitucional, tão discutida por uma certa «direita», de que fez parte Pacheco de Amorim, alterou o artigo $5 .^{\circ}$ da Constituição de 1933 , passando a ter a seguinte redacção:

O Estado Português é unitário, podendo compreender regiões autónomas com organização político-administrativa adequada à sua situação geográfica e às condições do respectivo meio social.

Por sua vez, no título VII, «Das Províncias Ultramarinas», o artigo 133.` passou a ser assim, sendo a novidade a "autonomia» e a possibilidade de serem as ditas províncias chamadas «Estados» (na designação tradicional, e meramente honorífica, tal como acontecera com o «Estado da Índia»):

Os territórios da Nação Portuguesa situados fora da Europa constituem províncias ultramarinas, as quais terão estatutos próprios como regiões autónomas, podendo ser designadas por Estados, de acordo com a tradição nacional, quando o progresso do seu meio social e a complexidade da sua administração justifiquem essa qualificação honorífica.

Porém, para não haver dúvida e confirmar o carácter unitário do Estado, o artigo $136 .^{\circ}$ tinha agora o seguinte texto:

O exercício da autonomia das províncias ultramarinas não afectará a unidade da Nação, a solidariedade entre todas as parcelas do território português, nem a integridade da soberania do Estado.

72 «Ao serviço do Império. Alocução proferida na abertura dos Cursos de Verão da Escola Central de Graduados em 2 de Agosto de 1943, no Instituto dos Pupilos do Exército (antigo Convento de S. Domingos de Benfica)", in Por Amor da Juventude, p. 173 ss.

${ }_{73}$ Francisco Sá Carneiro faz esta referência na sua entrevista, integrada no livro, que já citámos, Ser ou não ser deputado, pp. 10-11. 
Como se pode verificar, ficava-se pela ambiguidade, nunca formalizando qualquer ideia federativa e muito menos a possibilidade de qualquer ideia de autodeterminação. De resto, Marcello Caetano, desde o seu referido discurso de 15 de Setembro, pronunciou variados discursos a favor da posse portuguesa dos territórios ultramarinos de África, não criando, pelo menos no plano teórico ou das intenções expressas, qualquer inovação ${ }^{74}$. E é muito interessante ver como Marcello continua numa retórica de ambiguidade, mesmo nas suas Memórias, atribuindo a Salazar e aos seus discursos ideias diversas que vão da legitimidade da «autodeterminação», em certos casos e segundo certos métodos, à «integração», de acordo com lei de 1951, ficando-se por meras afirmações relativamente dúbias. Nas conversas - segundo relatava - com o então presidente do Conselho, ambos consideravam que a independência seria algo que necessariamente teria de acontecer, embora divergissem nos processos, considerando Caetano que, para o fim em vista, se deveria optar pela «autonomia progressiva». ${ }^{75}$

Essa posição estava, todavia, de acordo com as afirmações que Marcello produzira ao longo da sua vida política. Se será exagerada a posição de Fernando Pacheco de Amorim relativamente à sua tendência, manifestada desde sempre, para tornar independentes as "províncias ultramarinas», ou "colónias», como preferiu chamar-lhes ${ }^{76}$, pelo menos até aos anos cinquenta, parece indubitável que terá mantido basicamente uma lógica diferente de uma filosofia "assimilacionista» e, sobretudo, de «integração completa» no território político e social do país.

O jornalista Augusto Costa, em 1926, submeteu a dezasseis personalidades um inquérito que, já por si, implicitamente, constituía uma defesa do Império CoIonial Português ou, de acordo com o seu conceito, do «Império Português».

Entre as quatro perguntas formuladas, destaca-se a terceira:

Sim ou não Portugal, amputado das suas colónias, perderá toda a razão de ser como povo independente no conserto europeu?

O jovem Marcello Caetano foi um dos intelectuais inquiridos ${ }^{77}$. A essa questão respondeu de forma complexa, ou seja, dividiu-a em duas hipóteses. Na primeira, entendeu que a independência de Portugal na Península lbérica não estava, ob-

74 Ver Razões da presença de Portugal no Ultramar. Excertos de discursos proferidos pelo Presidente do Conselho de Ministros Prof. Marcello Caetano. 4. ${ }^{a}$ edição com índice ideográfico. Lisboa, SEIT, 1973.

${ }_{75}$ Minhas Memórias de Salazar, pp. 514-518.

${ }^{76}$ O próprio Salazar, mesmo no final dos anos cinquenta, continuava a gostar do uso da palavra «colónia», conforme dizia na entrevista citada ao jornal Le Figaro de 1958: «Para nós, a palavra colónia no seu mais puro significado continua a ser respeitável» (entrevista cit. a Serge Groussard, in Discursos, vol. VI, p. 11). E, no domínio das ideias, mantinha a mesma ideologia colonialista, de tipo «proteccionista»: «Nós cremos que há raças, decadentes ou atrasadas, como se queira, em relação às quais perfilhámos o dever de chamá-las à civilização...» («A Atmosfera Mundial e os Problemas Nacionais», discurso proferido em 1 de Novembro de 1957, ao microfone da Emissora Nacional, Discursos, vol. V, p. 427).

77 Augusto da Costa, Portugal vasto Império. Um inquérito nacional, Lisboa, Imprensa da Universidade, 1934, p. 49 ss. 
viamente, dependente das colónias: «A razão de ser de Portugal não está nas colónias, mas na diferenciação geográfica, étnica e histórica que o separa do resto da península». Na segunda hipótese, isto é, se Portugal, perdendo as colónias, perderia a sua força e a sua identidade e mesmo a sua "ordem», respondeu, numa reflexão conjuntural (tendo em conta o passado/presente republicano):

Se, por nosso mal, perdêssemos as colónias, a desorganização interna seria a mesma ou pior que anteriormente, após uma curta erupção de patriotismo retórico e de inflamada indignação. A perda das colónias? Seria o caos... ${ }^{78}$

Ou seja, num momento em que Portugal estaria ainda numa situação de «desordem" (1926, quando o inquérito foi realizado) e num tempo (1934, ano da publicação oficial do inquérito em livro, pela Imprensa Nacional), em que era ainda possível falar na possibilidade ou na certeza da independência das colónias a certo prazo, sobretudo de Angola, que viria a ser um «novo Brasil», e enquanto outros falavam já da integração das colónias, ou «províncias ultramarinas» (aliás na tradição vocabular monárquica e republicana portuguesa até aos anos vinte), no espaço político e oficial português, Marcello Caetano, pragmaticamente, apenas parece ter visto a questão colonial como um factor de complementaridade nacional. Isso, porém, não exclui que tivesse, de forma vaga e ambígua ou de forma expressiva no plano da posse e do estatuto «imperial» de Portugal, louvado os princípios e os métodos da colonização portuguesa ${ }^{79}$ e que não considerasse, como vimos, a colonização e o «Império» como realidades portuguesas em que os jovens se deveriam empenhar. Recordemos o seu papel de historiador e de administrativista que o levava a pensar nesses problemas.

No plano das opções e dos sentimentos políticas - não esqueçamos que Marcello, em diversas situações, mais ou menos oficiais, fez várias viagens ao Ultramar, começando com uma, em 1935, na qualidade de director pedagógico e cultural de um cruzeiro de férias para jovens, e que foi vogal do Conselho do Império Colonial, ministro das Colónias de 1944 a 1947 e, acima de tudo, foi chamado, no início dos anos cinquenta, a dar o seu parecer sobre as grandes alterações da política colonial ou ultramarina, como membro e presidente da Câmara Corporativa verificamos que a sua tendência, alegadamente em nome dos direitos especiais dos «indígenas» e contrariando a ideia assimilacionista, não era favorável, no íntimo, a uma modificação profunda na política portuguesa.

A mudança mais sensível opera-se em $1951^{80}$, por altura da revisão constitucional (Lei n. ${ }^{\circ} 2$ 048, de 11 de Junho). É então revogado o Acto Colonial de 1930, integrando-se as disposições sobre o «Ultramar» no título VII da própria Consti-

78 Ob. cit., p. 51.

79 Ver Tradições, princípios e métodos da colonização portuguesa, Lisboa, Agência Geral do Ultramar, 1951.

80 Sobre os temas que a seguir serão tratados, ver o nosso artigo «"Muitas raças, uma nação" ou o mito de Portugal multirracial na «Europa» do Estado Novo», in Estudos do Século XX, n. ${ }^{\circ}$ 2, «Europa-Utopia. Europa-Realidade». Coimbra, Quarteto - CEIS20, 2002, pp. 147-165. 
tuição, exactamente intitulado «Do Ultramar Português». Mas não há grandes alterações para além das modificações cosméticas que foram peculiares ao regime no pós-guerra. Com efeito, se, por pressões do tempo e para contrariar o processo de descolonização que então se iniciava, se altera o nome de "Colónias", voltando a chamar-se «Províncias Ultramarinas» (artigos 134. ${ }^{\circ}$ e $135 .^{\circ}$ ), e se elimina a designação de «Império» atribuída aos domínios ultramarinos portugueses, nada mais de essencial se modifica, nomeadamente no que diz respeito à «política indígena», embora se possa dizer que se começa a sentir a influência de uma paulatina política assimilacionista.

Mas, a Câmara Corporativa emitiu um parecer bem significativo, de que foi relator Marcello Caetano ${ }^{81}$. Embora aceitasse, por razões práticas, a alteração terminológica, ela não era considerada pacífica, votando alguns membros pela manutenção do nome de "Colónias» e outros por «Províncias Ultramarinas», enquanto a maioria se definiu pelo de «Territórios Ultramarinos». $E$ as razões transparecem no texto. Na verdade, a Câmara aceitava a mudança com o seguinte argumento: «Tal alteração parece justificar-se no presente momento, sobretudo pela campanha internacional contra a denominação e estatuto político das colónias" ${ }^{82}$. No entanto, manifesta o receio de que essa transformação conduzisse à adopção, na prática, da «assimilação» ou, melhor, de uma «assimilação prematura». São estas as palavras do parecer:

A Câmara chama muito particularmente a atenção para os perigos de uma assimilação prematura dos territórios ultramarinos e a metrópole.

As suas condições naturais são e permanecerão diferentes; diferentes, e muito, são também na maior parte deles as condições sociais e económicas.

Desta diferença que salta aos olhos do mais desprevenido observador resulta a necessidade da especialização do governo, da administração e das leis.

A assimilação tem de ser lenta, acompanhando a civilização dos nativos e o desenvolvimento dos núcleos de povoamento europeu. ${ }^{83}$

E, sendo assim, tão-pouco seria possível sujeitar todos os territórios a um regime uniforme, devendo prever-se diferenças, por vezes consideráveis, do estatuto orgânico, entre uns e outros, de acordo com a extensão, a população e o adiantamento de cada um.

As alterações verificadas na Constituição se levaram, portanto, à modificação dos nomes - para além do que foi dito, o Ministério das Colónias passou a chamar-se Ministério do Ultramar e o Conselho do Império Colonial Português designar-se-ia futuramente Conselho Ultramarino (artigo 150..$^{\circ}$ - , não se alteraram, como se disse, no essencial, as concepções quanto às populações «indígenas».

\footnotetext{
${ }^{81}$ Parecer da Câmara Corporativa n. ${ }^{\circ}$ 10/V , in Diário das Sessões, n. ${ }^{\circ}$ 70, de 19 de Janeiro de 1951.

${ }^{2}$ Parecer in Diário cit., II, Exame na especialidade, 11.

${ }^{83}$ Idem, I Apreciação na generalidade, 3.
} 
Com efeito, nunca a situação dos «indígenas» foi tão bem definida, como no Estatuto dos Indígenas Portugueses das Províncias da Guiné, Angola e Moçambique (decreto lei n. ${ }^{\circ} 39666$, de 20 de Maio de 1954). $O$ artigo 2. ${ }^{\circ}$ é particularmente interessante quanto à definição do «indígena»:

Consideram-se indígenas das referidas províncias os indivíduos de raça negra ou seus descendentes que, tendo nascido ou vivendo habitualmente nelas, não possuam ainda a instrução e os hábitos individuais e sociais pressupostos para a integral aplicação do direito público e privado dos cidadãos portugueses.

Portanto, apesar de alguma modificação formal, mantinha-se uma política de «proteccionismo» ou, quando muito, de «associação e cooperação» com os povos «indígenas», considerando-se no mesmo estatuto as condições necessárias para que um «indígena» se tornasse «cidadão português». E esta política se não se deve às posições de Marcello Caetano pode dizer-se que se ajusta, basicamente, às ideias por ele defendidas. De resto, nesse ano de 1954, publica o livro Os nativos na economia africana ${ }^{84}$.

Devido, sem dúvida, às pressões internacionais e às primeiras ameaças da «guerra colonial», bem como às ideias de Adriano Moreira, só em 1961 (decreto lei n. ${ }^{\circ} 43893$, de 6 de Setembro de 1961) é derrogado, em artigo único, o aludido decreto lei que sancionava o «estatuto» dos «indígenas portugueses». Entretanto, o preâmbulo justificativo consta de quase três colunas compactas, em que o Ministro do Ultramar, sem dúvida o seu redactor, procurou justificar não só esta medida, mas igualmente o estatuto do indigenato que - segundo o texto - tinha apenas como finalidade, dentro da «tradição portuguesa», respeitar o "direito privado das populações» e não propriamente negar a "cidadania» aos «indígenas», que não devia ser confundida com «a capacidade de gozo e exercício de direitos políticos relacionados com as novas formas dos órgãos de soberania». Desta forma hábil, procurava-se provar que se estava a avançar no sentido da «assimilação», tentando ao mesmo tempo mostrar que, ao contrário das «fáceis e interessadas críticas dos nossos detractores» ao estatuto dos «indígenas», este decreto era, afinal, apenas mais «um passo em direcção aos objectivos anteriormente fixados». Então Marcello estava fora da política do Estado Novo, como Reitor da Universidade de Lisboa.

\section{A CONCLUIR OU... A PROSSEGUIR}

Como se viu, é importante estudar e aprofundar o conhecimento das ideias de Marcello Caetano antes de ocupar a pasta da Presidência do Conselho, que abriu as portas ao chamado "Marcelismo". E este não pode ser visto apenas no seu tempo, nem em função dos «marcelistas» ou das memórias do próprio Marcello, ou mesmo de uma interpretação incorrecta das suas afirmadas discordância com

${ }^{84}$ Os nativos na economia africana, Coimbra, Coimbra Editora, 1954. 
Salazar. Tem de ser entendido em função de uma complexidade de factores, em que um deles - e talvez o mais importante - é o próprio Marcello, estudado desde, pelo menos, 1926 até 1959, altura em que é nomeado Reitor da Universidade de Lisboa, ou até mais além, quando faz a «travessia no deserto». Esta comunicação não pretende ser uma investigação alargada e aprofundada, mas uma hipótese para uma investigação.

Acima de tudo, o que quisemos é fugir da lógica ou, tão-só, da imagem que nos apresenta o Marcelismo como um fenómeno de «liberalização» («bloqueada», pelos «ultra» do regime, mesmo que estes tivessem existido, como efectivamente existiram, e tivessem «bloqueado» qualquer hipótese de «actualização» do sistema) e, muito menos, de «transição falhada» ${ }^{85}$. Não o foi basicamente, pois o regime manteve-se, na essência, com a mesma estrutura. De resto, Marcello Caetano, na célebre entrevista dada a Alçada Baptista, em 1973, ironizava até sobre parlamentarismo de «modelo inglês», em especial para Portuga| ${ }^{86}$. E sempre se opôs nos seus discursos à democracia liberal. De resto, sempre defendera a fórmula «realista» e «relativista» - fundamentada na ideologia tradicionalista e neo-tradicionalista ou integralista, que voltava a referir nas suas Memórias, pela boca de Salazar, num «memorável discurso» - de que o melhor regime possível para um povo era o que se adaptava melhor às suas condições internas e externas ${ }^{87}$. Poderia o regime de Marcello Caetano aparentar uma forma mais liberal no que dizia respeito à censura, à educação, às relações internacionais, à economia, à política ultramarina... mas mantinham-se todas as estruturas do Estado Salazarista: a estrutura da «República Corporativa» (Constituição, artigo 5., § 1. ${ }^{\circ}$ ), a Secretaria de Estado de Informação e Turismo (a dar nova cor ao Secretariado Nacional de Informação, SNI, que substituíra o Secretariado de Propaganda Nacional, SPN), a Acção Nacional Popular (a substituir a UN), mantinham-se a Censura e uma lei da Imprensa pouco liberal, a Direcção Geral de Segurança (a substituir a Polícia Internacional e de Defesa do Estado, PIDE, que por sua vez substituíra a Polícia de Vigilância e de Defesa do Estado, PVDE)...

85 Note-se o título do livro coordenado por Fernando Rosas e Pedro Aires de Oliveira, $A$ transição falhada. O Marcelismo e o Fim do Estado Novo (1968-1974), Lisboa, Editorial Notícias, 2004. Na capa aparecem enunciadas as seguintes questões: «Foi o marcelismo um salazarismo sem Salazar? Era possível a transição a partir do regime? O que falhou realmente em Marcello?» Estas perguntas, muito interessantes, já parecem evidenciar um programa de análise, com que nem sempre estamos de acordo. Não lhes quisemos responder directamente, mas verificamos agora que, de algum modo, lhes respondemos, como mera hipótese de trabalho (repetimos).

${ }^{86}$ Cfr. António Alçada Baptista, Conversas com Marcello Caetano, Lisboa, Moraes Editores, 1973, pp. 49-50.

87 Cfr. As Minhas Memórias..., p. 201. Marcello Caetano cita o seguinte passo de um discurso de Salazar, realizado no fim da guerra: «Cada país em que os dirigentes políticos têm plena noção das suas responsabilidades há-de ter as instituições que melhor se adaptem ao seu modo de ser e dele façam elemento prestante da comunidade internacional e há-de conceder e garantir aquele grau de liberdade consentâneo com a eficiência das disciplinas interiores do homem e exteriores do meio social. Sem isso não haverá ordem e progresso interno nem colaboração que preste com as mais nações» («Portugal, a guerra e a paz», proferido em sessão da Assembleia Nacional de 18 de Maio de 1945, in Salazar, Discursos, vol. IV, p. 116). 
Mesmo a lógica de um «rotativismo» (que Caetano considerara um sistema faIhado já na Monarquia Constitucional ${ }^{88}$ ), num contexto «nacional» e «corporativo», parecia estar posto de parte nas vésperas do 25 de Abril ou em 1968, como prova aliás a experiência da «ala liberal», que surgiu não como alternativa à União Nacional (depois de 1970, Acção Nacional Popular), mas dentro da própria UN e sujeita afinal às suas regras restritas, fiscalizadas pelos «ultra», por salazaristas ou mesmo por outras correntes, salazaristas-marcelistas. Nas suas Memórias de Salazar, que devem ser lidas e relidas, mas criticamente, Caetano, referindo à UN já não fala - aliás, como Salazar e como considerava a versão mais oficial - em "partido único», como lhe chamava em 1938, mas numa organização «antipartidária». E referindo-se a um discurso que proferiu em 19 de Fevereiro de 1948, diz ter então afirmado que se a UN não era um «partido" ainda menos poderia ser "um feixe de partidos» ${ }^{89}$. Ao referir, assim, o seu pensamento, em anos recuados, justificava, com certeza, a destruição da «ala liberal» na UN/ANP. A experiência provara-lhe que o que sucedera era a tendência para se criar esse «feixe de partidos", o que estava fora de toda a sua perspectiva política. Mesmo quando fala expressamente da "oposição", nessas mesmas Memórias, tem sempre a ideia de que ela apenas deveria ter «o propósito de promover uma evolução progressiva do regime», mas nunca deveria ser uma verdadeira oposição ao regime, o que provocaria a sua destruição ${ }^{90}$. Quando muito aceitou a mudança de palavras e a abertura limitada que tal acabaria por trazer, bem como a mudança necessária que as pressões internacionais impunham, tal como no pós-guerra se passou a falar o próprio Salazar o fez, ele que se confessara «antidemocrata»"1 _, para caracterizar o regime português, de «democracia orgânica». Por isso, Marcello preferia ao conceito de Estado Novo, já gasto, o de «Estado Social». Tal como Salazar afirmara, no tal "discurso memorável» que Marcello referira nas suas Memórias: "se a democracia pode ter, além do seu significado político, significado social, então os verdadeiros democratas somos nós" ${ }^{92}$. Isso iludiu muita gente, mesmo no estrangeiro e apesar da queda dos regimes autoritários/totalitários em que o de Salazar se incluía, como, mais tarde, nos anos sessenta e setenta, em período grave de «guerra colonial», o Marcelismo iludiu também. E continua por certo a iludir...

Portanto, o Marcello Caetano de 1974 não nos parece substancialmente diferente do Marcello de 1926 ou de 1940 ou de 1968, pelo que o Marcelismo não é fundamentalmente diferente do Salazarismo. Ele é afinal um Estado Novo sem Salazar e... com Marcello Caetano, personalidade diferente de Salazar. É a tal «renovação na continuidade», mais "continuação» do que «renovação» do regime.

${ }^{88}$ Cfr. A. Alçada Baptista, ob. cit., pp. 49-50.

89 As Minhas Memórias..., pp. 289 ss. e 306.

90 Ob. cit., p. 247.

91 Dizia Salazar em 1940: «nós que nos afirmamos por um lado anti-comunistas e por outro anti-democratas e anti-liberais, autoritários e intervencionistas[...]» (Discurso proferido na Assembleia Nacional, em 25 de Maio de 1940, durante a sessão em que a câmara aprovou a Concordata e o Acordo Missionário, assinados no Vaticano em 7 de Maio anterior, in Discursos, vol. III, Coimbra, Coimbra Editora, s. d., p. 236).

92 Discurso cit. «Portugal, a Guerra e a Paz», Discursos, IV, pp. 119-120. 